\title{
Investigating the Determinants of Consumers' Attitude towards Social Media Marketing: Moderating Role of Gender
}

\author{
Madeeha Irshad \\ Department of Management Sciences, COMSATS University Islamabad, PAKISTAN \\ (iD) 0000-0002-5458-4078 \\ madeeha_scorpion@hotmail.com
}

\section{Muhammad Shakil Ahmad}

Department of Management Sciences, COMSATS University Islamad, Attock campus, Attock, 43600, PAKISTAN

(iD) 0000-0002-2458-3082

onlyshakil@gmail.com

ARTICLE INFO

Received: 25 April 2019

Accepted: 30 June 2019

Published: 28 July 2019

DOI: https://doi.org/10.29333/ojcmt/5865

ABSTRACT

Social media marketing is a trending topic in marketing research. However the research on its effectiveness is still at embryonic stage. Marketers are faced with challenging issues of identifying consumers' motivations that affect subsequent trust on social media retailers and attitudes of consumers with respect to social media marketing. The aim of the present research is to address these gaps and identify the impact of consumers' socialization motivation on consumers' attitude towards social media marketing and trust on social media retailers. In addition to this, the study identifies the moderating role of gender in affecting the relationship between socialization motivation, trust and attitude towards social media marketing. Data were collected from three cities of Pakistan. Structural equation modelling through AMOS was used to test the hypotheses. The results revealed that socialization motivation has a positive impact on consumer' trust on social media retailers. Moreover, socialization motivation has a positive impact on consumers' attitude towards social media marketing. Trust on social media retailers has a significant positive impact on consumers' attitude towards social media marketing. Gender was found as an important moderating variable in affecting the path estimates among different variables of the research model. The study has important theoretical and managerial implications and concludes with few limitations and future research directions.

Keywords: social media marketing, attitude, socialization, trust

\section{INTRODUCTION}

Internet is reshaping the world and our daily activities (Michopoulou \& Moisa, 2019). The popularity of internet is also leading towards the evolving role of promotional mix in marketing communications (Pantano et al., 2019; Shankar \& Batra, 2009). Companies are moving beyond traditional modes of communication like television, newspapers and magazines etc. and increasingly adopting newer modes of communication like Internet and social media (Irshad, 2018; Pletikosa Cvijikj \& Michahelles, 2013). In the past few Copyright ( 2019 by OJCMT 
years, the world has witnessed an increased growth in information that is generated and shared through social media (Jabeur, Nait-Sidi-Moh, \& Zeadally, 2017). Social media is defined as a platform that encompasses social networking sites and mobile messaging applications that is used by people to communicate with friends and family, and to share updates, photos and videos about their daily lives (Hawk, van den Eijnden, van Lissa, \& ter Bogt, 2019).

There are different channels of social media that comprise of social networking sites like Facebook, video sharing sites like YouTube, photo sharing sites like Instagram, microblogging sites like Twitter, business networking sites like LinkedIn and other applications like Snapchat etc. (Vo et al., 2019). Among these different channels, Facebook occupies the top most position in terms of number of users that are about 2.7 billion (Statista, 2019a). Twitter has 330 million monthly active users (Statista, 2019c), Instagram had reached 1 billion active monthly users by the end of June 2018 (Statista, $2019 b)$, YouTube is one of the biggest online video platforms and its users are about 2 billion (Statista, 2019e), whereas Pinterest has 265 million active monthly users (Statista, 2019d). Social media is an integral component of daily lives of people and they are found to be inclined to move their interactions to virtual platforms like Facebook, Twitter and Instagram etc. (Alalwan, Rana, Dwivedi, \& Algharabat, 2017). Companies use variety of these social media platforms to attain different objectives (Valos, Habibi, Casidy, Driesener, \& Maplestone, 2016). The rapid development of mobile internet further promotes the increased use of social media to communicate with others (Zong, Yang, \& Bao, 2019).

Consumers use social media for various purposes (Dijkmans, Kerkhof, \& Beukeboom, 2015). Some people use social media for finding products and information search (Mowbray, Hall, Raeside, \& Robertson, 2017), while others use it for comparing product features and prices among different brands (Erkan \& Evans, 2018). The tremendous popularity of social media has captured the attention of marketers since it is deeply penetrated into our daily lives (Alalwan, 2018). People spend about 2 hours and 18 minutes on social media per day worldwide (GWI, 2019a). People in Asia Pacific spend 2 hours and 13 minutes on social media per day, people in Europe spend 1 hour and 50 minutes on social media per day, people in Latin America spend 3 hours and 27 minutes on social media per day, people in Middle East and Africa spend 3 hours and 3 minutes on social media per day and people in North America spend about 2 hours and 4 minutes on social media per day (GWI, 2019b). These statistics reveal the huge popularity of social media among people around the world.

The increasing popularity of social media has also attracted the attention of marketers. The emergence of social media as a marketing tool has changed the dynamics of marketing in terms of companies' interactions with consumers and sharing information about the brands (Parsons \& Lepkowska-White, 2018). Thus social media marketing is considered as an essential element of promotional mix of companies. Social media marketing that comprises of interactive advertising and online brand communities (Chi, 2011), explicit and implicit advertising (Taylor, Lewin, \& Strutton, 2011) has attracted the attention of many research scholars (Akar \& Topcu, 2011). Due to the trending topic of social media marketing, the Marketing Science Institute has set different priority areas that cover exploring the consumer behavior with respect to social media marketing (MSI, 2014). Almost $96 \%$ of the companies are engaged in social media marketing (Melancon \& Dalakas, 2018). However, the research about the effectiveness of social media marketing strategies in terms of affecting consumers' attitudes and behavioral intentions is still 
debatable and at an embryonic stage (Irshad, 2018; Zhang \& Mao, 2016). This issue prevails in developed countries of the world like US (Zhang \& Mao, 2016) as well as in the Asian developing countries (Dao, Le, Cheng, \& Chen, 2014; Irshad, 2018). The issue is important to be addressed because social media marketing is still in its iterative years in the Asian countries and the internet infrastructure is not as well developed in these countries as compared to the advanced countries of the world (Dao et al., 2014; Jung, Shim, \& Jin, 2015; Luna-Nevarez \& Torres, 2015).

Considering the fact that the consumers are exposed to marketing content on social media like ads and brand pages etc., it becomes vital to understand the factors that affect consumers' attitude, trust and behavioral intentions in social mediated marketing environment (Irshad, 2018; Luna-Nevarez \& Torres, 2015; Wang, Min, \& Han, 2016). Researchers are of the view that insufficient knowledge about consumers' motivations with respect to social media marketing is one of the reasons behind lack of understanding about the effectiveness of social media marketing strategies (Zhang \& Mao, 2016; Zhu \& Chen, 2015). Consumers' motivations are defined as psychological needs, wants, desires and drives in decision making processes of consumers (Kumar \& Kashyap, 2018; Xie \& Ritchie, 2019). However, there is dearth of knowledge about consumers' motivations in the social media marketing environment (Irshad, 2018; Zhang, Guob, Huc, \& Liu, 2016).

Prior studies on social media marketing have mainly focused on utilitarian and hedonic motivations of consumers in the context of social media marketing leaving room for studying other types of consumers' motivations (Anderson, Knight, Pookulangara, \& Josiam, 2014; Pöyry, Parvinen, \& Malmivaara, 2013). Besides this, trust is also understudied in the context social mediated environment (Wang et al., 2016). Apart from this, another research gap is that most of the prior studies on social media marketing lack explicit theories and testable hypotheses (Knoll, 2015). Therefore the aim of present research is to address all these gaps and present a testable comprehensive model of consumer behavior with regard to social media marketing environment.

An important point to note is that social media advertising is a general term that captures all forms of implicit advertising like banner ads and commercial videos as well as explicit advertising like brand pages and company related tweets (Taylor et al., 2011). Chi (2011) also stated that there are two types of marketing communications in social media which include interactive digital advertising and brand communities or pages. Therefore, in this research the term "social media marketing" is synonymously used with social media advertising.

\section{THEORETICAL BACKGROUND AND HYPOTHESES}

The present study is based on Uses and Gratifications Theory and Theory of Reasoned Action to understand the interplay between motives, trust on social media retailers and attitude towards social media marketing. Uses and Gratifications Theory is considered as one of the most prominent and popular theories to understand underlying consumers' motives and their subsequent impact on attitudinal and behavioral outcomes (Plume \& Slade, 2018). Originally, UGT was applied to study the media users' interest in the traditional forms of media like newspapers, television, radio, and telephone but now its applicability has also been expanded to other areas of research (Corkindale, Ram, \& Chen, 2018; Thongsri, Shen, Bao, \& Alharbi, 2018). The main purpose of Uses and Gratifications Theory is to explain the reasons on the basis of which individuals choose a particular medium over other alternative media (Dolan, Conduit, Fahy, \& Goodman, 2016) . It is considered as a well-known and highly valid theory because its principles are generally 


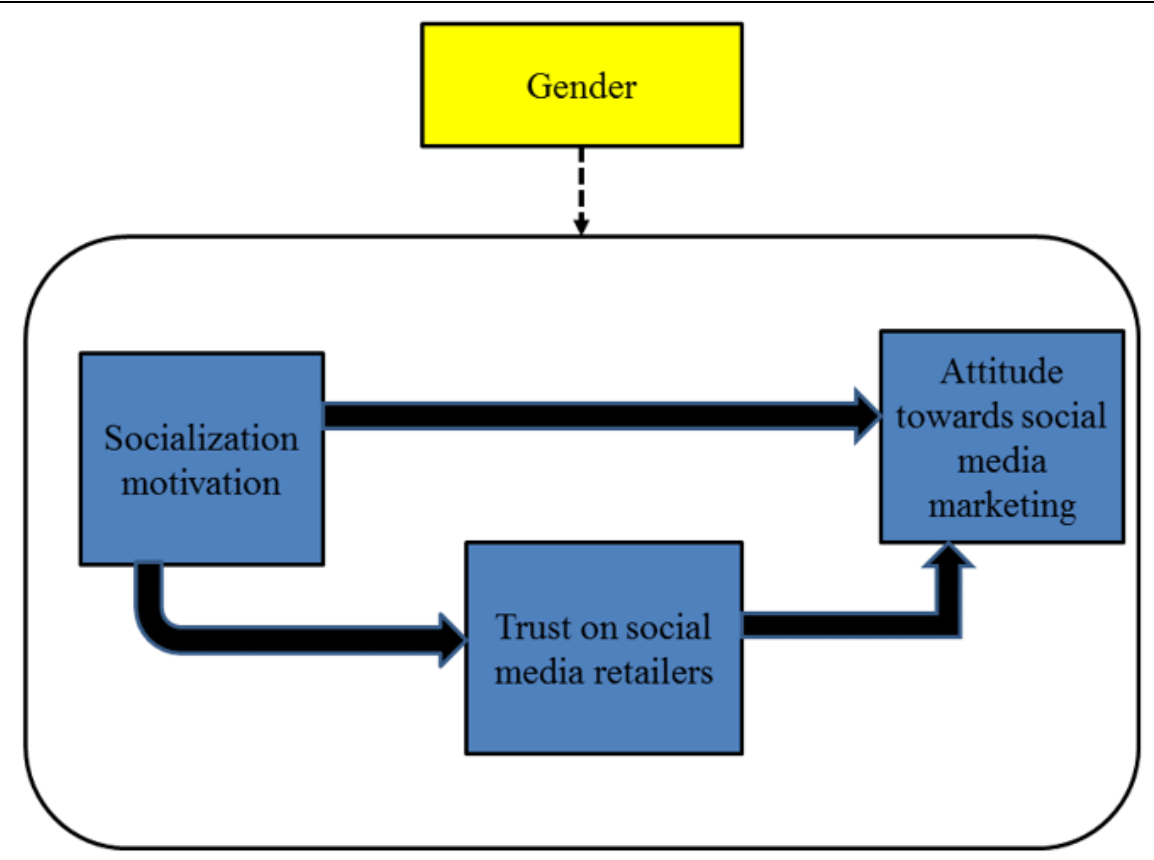

Figure 1. Research Model

accepted and can be applied in many situations (Liu, North, \& Li, 2017; Plume \& Slade, 2018). UGT is a comprehensive framework that identifies consumers' motivations and has evolved over the years (Hossain, 2019; Mishra, 2019; Zong, Yang, \& Bao, 2019).

Theory of Reasoned Action is used to understand the impact of underlying factors e.g. trust on the attitudes and behavioral intentions of consumers in the online environment (Xu-Priour, Truong, \& Klink, 2014). Theory of Reasoned Action is also very useful to understand different types of consumer behaviors with regard to any technological use (Nwagwu \& Famiyesin, 2016). Therefore, we extracted trust from the Theory of Reasoned Action as supported by prior studies (Xu-Priour et al., 2014).

Motivations are defined as desires to achieve goals (Chiang \& Hsiao, 2015). It is important for both online and offline stores to be knowledgeable about consumers' motivations that play a part in consumers' purchasing activities (Zhu \& Chen, 2015). Trust is defined as one's party willingness to rely on another party despite having no ability to control or monitor that party (Lin, Wang, Wang, \& Lu, 2014), Attitude refers to the consumers' favorable or unfavorable evaluations about anything in order to perform a behavior (Kim \& Chung, 2011).

The current research focuses on socialization motivation as potential predictor of consumers' attitudes towards social media marketing, trust towards the retailers present on social media and online purchase intentions as discussed in sub sequent sections.

\section{SOCIALIZATION MOTIVATION}

With the emergence of web 2.0 and social media, consumers can get connected to other like-minded people and socialize with them (Hilverda, Kuttschreuter, \& Giebels, 2017). Through the socialization processes and communication with peers, individuals develop beliefs, feelings and responses (Aladwani, 2018). Interaction with peers facilitates the provision of a comfortable environment to individuals and they can rely on their peers for emotional, informational and attachment needs (Gentina, Shrum, Lowrey, Vitell, \& Rose, 2018). Individuals can discuss their product related needs with traditional socialization 
agents like parents as well as their friends and other like-minded people on social media (Mishra, Maheswarappa, Maity, \& Samu, 2018). Peers play a vital role in influencing the buying behavior of consumers (Paul, Modi, \& Patel, 2016). In Asian Pacific countries, digital media is frequently used by people to gain opinions of their peers to assess the credibility of whatever they see (eMarketer, 2016). However, there is dearth of research on the impact of peer communication in social mediated marketing environment (Hilverda et al., 2017; Muralidharan \& Men, 2015; Zhang \& Mao, 2016). Thus it is hypothesized that:

H1a: Socialization motivation has a significant positive influence on consumers' attitude towards social media marketing

H1b: Socialization motivation has a significant positive influence on consumers' trust on social media retailers.

\section{TRUST AND ATTITUDE}

Trust refers to reliance on another person or entity (Kaushik, Agrawal, \& Rahman, 2015). In business transactions, trust is used as a corner stone of relying on another party (Pirson, Martin, \& Parmar, 2017). It is considered as a fundamental aspect in business to business (Ashnai, Henneberg, Naudé, \& Francescucci, 2016) and business to consumer dealings (Wang et al., 2016). Several studies show that trust acts as an important variable in affecting consumers' attitude (Aziz, Husin, Hussin, \& Afaq, 2019). Due to the uncertain nature of cyberspace, trust has been identified as a direct determinant of consumers' attitude (Al-Debei, Akroush, \& Ashouri, 2015). Hence, it is assumed that trust is important to exist in social media environment in order to positively influence consumers' attitude towards social media marketing as there is absence of face to face interaction.

H2: Trust positively influences consumers' attitude towards social media marketing.

\section{MODERATING ROLE OF GENDER}

Very few studies have analyzed the moderating role of gender in e commerce and social commerce environment (Nadeem, Andreini, Salo, \& Laukkanen, 2015). Females have been found to have more positive attitude towards online shopping as compared to males (Dittmar, Long, \& Meek, 2004). Male and female consumers differ in their behaviors in various decision-making situations (Shao, Zhang, Li, \& Guo, 2019). As compared to males, females have more anxiety when they are indulged in new activities like online shopping and they are less likely to take risks (Shao et al., 2019). Hence, it is hypothesized that:

H3a: Gender moderates the path estimates between socialization motivation and consumers' attitude towards social media marketing

H3b: Gender moderates the path estimates between socialization motivation and consumers' consumers' trust on social media retailers

H3b: Gender moderates the path estimates between consumers' consumers' trust on social media retailers and consumers'attitude towards social media marketing.

\section{MATERIALS AND METHODS}

Social media is used by many fashion brands for commercial purposes like influencing consumers' purchase related matters (Godey et al., 2016). However, anticipating consumer behavior in social mediated environment is challenging for fashion industry around the world including Pakistan (PAS, 2015). Thus, the current study was based on the Pakistani fashion industry. The items of socialization motivation were adapted from 
Table 1. Reliability and Convergent Validity

\begin{tabular}{lcc}
\hline & CR & AVE \\
\hline Socialization Motivation & 0.897 & 0.635 \\
Attitude towards social media marketing & 0.884 & 0.523 \\
Trust on social media retailers & 0.868 & 0.572 \\
\hline
\end{tabular}

Wang, Yu and Wei (2012), items for attitude towards social media marketing were adapted from Akar and Topcu (2011), and items for trust towards the retailers present on social media were adapted from Van Der Heijden, Verhagen and Creemers (2003).

We collected data from the people residing in Karachi, Lahore and Islamabad as people in these cities are well-educated, earn good income and are knowledgeable about the brands as many national and multi-national brands have their outlets in these cities (PBS, 2013). We distributed questionnaires in different universities in these cities as university students are well aware about technology and spend ample amount of their time in using internet (Ahmad, Mustafa, \& AhsanUllah, 2016; Ashraf, Thongpapanl, \& Auh, 2014). However, collecting data only from the university students is considered as a limitation with respect to the generalization of results. Thus the data were collected from university students as well as working employees in the universities, educational institutions, banks and other business sectors. Data were also collected using an online version of the questionnaire. In order to make sure that respondents use social media for commercial purposes or not, they were asked in the preamble to fill out the questionnaire provided they use social media for commercial purposes and those who did not use it for commercial purposes were asked not to fill it. Besides this, they were also told in the preamble to fill the questionnaires keeping fashion retailers on social media in mind. We obtained 574 completely filled questionnaires after discarding the questionnaires which had large number of missing responses.

\section{RESULTS}

The results of demographic analysis revealed that $51 \%$ of the respondents were female and $49 \%$ were male. This implies that there was almost equal representation of males and females. Most of the respondents fell in the age bracket of 26-30. Most of the respondents were well educated i.e. 38\% had Masters degree followed by MS degree [28\%]. About 56\% of the respondents were employed. With respect to income the highest percentage of respondents [i.e. 32\%] were earning about RS. 50 thousand to RS. 1 lac per month.

We followed two step approach. In this section, we applied the two-step approach of Anderson and Gerbing (1988). Confirmatory Factor Analysis was conducted in order test the measurement model. Amos 21 was used. Different fit indices are reported for model fitness (Kline, 2016). The results show that the measurement model had reasonable fit indices with CFI: 0.913, CMIN/DF: 3.319, RMSEA: 0.055 and SRMR: 0.0492.

One criterion to estimate convergent validity is that each factor loading should be at least 0.5 (Anderson \& Gerbing, 1988). One item of trust having loading of 0.10 was eliminated. Convergent validity is demonstrated by the measurement model because the average variance extracted [AVE] for each of the factors is greater than 0.5 (Fornell \& Larcker, 1981). Scale reliability is verified since the values of composite reliability indices for all the factors are greater than 0.6 (Hair, Black, Babin, \& Anderson, 2010).

Our constructs also possessed discriminant validity as well as the square root of AVE for each construct was greater than the correlations among constructs. All constructs shared more variance with their respective indicators than with other constructs of the model. 
Online Journal of Communication and Media Technologies, 2019

Table 2. Discriminant Validity

\begin{tabular}{|c|c|c|c|}
\hline & 1 & 2 & 3 \\
\hline 1 Socialization Motivation & $0.713^{* * *}$ & & \\
\hline 2 Attitude towards social media marketing & $0.106 * * *$ & 0.723 & \\
\hline 3 Trust on social media retailers & $0.302^{* * *}$ & $0.254^{* * * *}$ & 0.756 \\
\hline
\end{tabular}

Table 3. Structural Model Results

\begin{tabular}{|c|c|c|c|c|}
\hline Hypotheses & Hypothesized Relationships & $\beta$ & p & Decision \\
\hline H1a & $\begin{array}{l}\text { Socialization Motivation-Consumers' attitude } \\
\text { towards social media marketing }\end{array}$ & 0.577 & $* * *$ & Accepted \\
\hline H1b & $\begin{array}{l}\text { Socialization Motivation-Consumers' Trust on social } \\
\text { media retailers }\end{array}$ & 0.370 & $* * *$ & Accepted \\
\hline H2 & $\begin{array}{l}\text { Consumers' Trust on social media retailers- } \\
\text { Consumers' attitude towards social media marketing }\end{array}$ & 0.455 & $* * *$ & Accepted \\
\hline
\end{tabular}

Note: Significant at $* * * p<0.001$, [two-tailed test]; 8 , standardized path coefficients

Table 4. Multi Group Moderation

\begin{tabular}{clccc}
\hline Hypotheses Hypothesized Relationships & Female & Male & Z score \\
\hline H3a & $\begin{array}{l}\text { Socialization Motivation-Consumers' attitude } \\
\text { towards social media marketing }\end{array}$ & 0.50 & 0.30 & $3.12^{* * *}$ \\
H3b & $\begin{array}{l}\text { Socialization Motivation-Consumers' Trust on social } \\
\text { media retailers }\end{array}$ & 0.42 & 0.18 & $2.28^{* * *}$ \\
H3c & $\begin{array}{l}\text { Consumers' Trust on social media retailers- } \\
\text { Consumers' attitude towards social media marketing }\end{array}$ & 0.48 & 0.22 & $2.12^{* * * *}$
\end{tabular}

We the tested our structural model. The structural model also revealed good fit indices i.e. $\mathrm{CFI}=0.915, \mathrm{CMIN} / \mathrm{DF}=2.902, \mathrm{RMSEA}=0.058$ and $\mathrm{SRMR}=0.0426$. The results revealed that there is a significant positive impact of socialization motivation on consumers" attitudes towards social media marketing [ $[B=0.577, p<0.001]$ and trust towards the retailers present on social media $[B=0.370, p<0.001]$ which lead us to accept $\mathrm{H} 1$ and H1b. Trust on social media retailers has significant positive influence on consumers' attitude towards social media marketing $[B=0.455, \mathrm{p}<0.001]$ which leads us to accept $\mathrm{H} 2$.

Gender moderates the path estimates among all variables in the research model as shown in Table 4. Thus H3a, H3b and H3c are accepted.

\section{DISCUSSION}

In response to the popularity of social media platforms, marketers have started to use these platforms as promotional tools. There is a growing interest among researchers to identify factors that affect consumers' attitudes and behavioral responses like purchase intentions with respect to social media marketing. Besides this, there is a dire need to understand consumers' trust in social mediated marketing environment. Although numerous factors can affect consumers' attitudes, trust and online purchase intentions, one possible factor is consumers' motivations with regard to social media marketing. However, there is dearth of knowledge about consumers' motivations from commercial aspects keeping in view social mediated marketing environment. Previous studies on social media marketing were generally based on information and entertainment motivations of consumers. However, there are a number of other consumers' motivations that are important to be addressed in studies involving social media marketing. To this end, the present study introduced socialization motivation to understand its role in influencing consumers' attitude towards social media marketing, trust on social media retailers and online purchase intentions. Our results show that socialization motivation 
has significant influence on attitude towards social media marketing and trust on social media retailers. These results are supported by previous studies. The empirical support of these hypotheses is consistent with previous studies in the context of offline and web 1.0 environment (Niu, 2013). Communication and interactions with peers exert a significant influence in shaping consumers' attitudes in both offline and online setting. Consumers that engage in online communication and interaction with their peers show positive attitude towards social ads as compared to individuals that do not get engaged in online peer communication (Zarouali, Poels, Walrave, \& Ponnet, 2018). Peer communication i.e. social influence has been found to exert significant positive impact on consumers' attitudes towards mobile advertising and SMS advertising (Izquierdo-Yusta, Olarte-Pascual, \& Reinares-Lara, 2015; Muk \& Chung, 2015). Thus these results confirm to the previous studies regarding the significant and positive impact of socialization motivation on consumers' attitude in social mediated marketing context.

Trust has a significant positive impact on consumers' attitude towards social media marketing which aligns with previous studies (Aziz et al., 2019). This finding confirms to the previous studies in online shopping context as trust is a critical factor in shaping consumers' attitudes in online shopping environment (Rahman, Islam, Esha, Sultana, \& Chakravorty, 2018). Besides this, this finding also aligns with advertising literature as trust is identified as an important determinant in shaping consumers' attitude towards advertising (Ball, Manika, \& Stout, 2016). Thus, it is concluded that trust on social media retailers in shaping consumers' attitude is as important in social mediated marketing contexts as it is important in advertising and online shopping contexts. Gender moderates the relationship between socialization motivation, trust and attitude towards social media marketing which is in congruence with previous studies (Shao et al., 2019). The moderating effect of females is stronger for each path estimate as compared to males. This might be due to the fact that females are more associated with fashion products as compared to males (Mosquera, Olarte-Pascual, Ayensa, \& Murillo, 2018). The current study has important theoretical contributions. The foremost theoretical contribution of the current study is the integration of Uses and Gratifications Theory and Theory of Reasoned Action. This fills an important gap in literature as identified by prior studies where most of the research conducted on the social media advertising field lacked a specific particular theory or referred to a particular in order to generate testable model and hypotheses (Knoll, 2015). The integration of Uses and Gratifications Theory and Theory of Reasoned Action contributes to new knowledge in the existing body of literature. The present study helps in understanding the applicability of Uses and Gratifications Theory and Theory of Reasoned Action in the context of social media marketing and also suggests that different aspects of consumer behavior can be taken into consideration by integrating Uses and Gratifications Theory and Theory of Reasoned Action.

Another theoretical contribution of the present study is testing the proposed theoretical framework with respect to the fashion industry. Thus, the present research helps in deepening our understanding about consumer behavior in the fashion industry by incorporating important variables as socialization motivation, attitude towards social media marketing and trust on social media retailers. Apart from all the above mentioned theoretical contributions, the present study takes into account the Pakistani context because Pakistan is an emerging economy where social media marketing is still in its iterative years so understanding consumer behavior with respect to social media marketing in a developing country like Pakistan provides important theoretical insights. This also fills an existing gap in literature where majority of the previous studies were 
conducted in the developed countries (Odoom, Anning-Dorson, \& Acheampong, 2017). We took a step ahead from previous studies in social media marketing context that were based on utilitarian and hedonic motivations (Irshad, 2018; Muk, Chung, \& Kim, 2014) and incorporated understudied motivation i.e. socialization motivation and determined the linkage between these socialization motivation, attitude, trust and online purchase intentions.

\section{MANAGERIAL IMPLICATIONS}

The study also provides several managerial implications. The results revealed that satisfying the socialization need of consumers leads towards the establishment of positive attitudes towards social media marketing and trust on social media retailers. This suggests that consumers visit social media sites to see what products are liked by their peers and thus they seek opinion from them. Therefore, the retailers on social media should emphasize a lot in providing social benefits to the consumers by providing them more opportunities for member-to-member interactions on the companies' social media profile pages in order to give them sense of belongingness with like-minded peers. Trust has a significant positive influence on consumers' attitude towards social media marketing. Therefore the managers should focus on fulfilling their commitments with customers in terms of providing good quality products to customers, return policies and high quality product information.

\section{LIMITATIONS AND FUTURE RESEARCH DIRECTIONS}

Despite the interesting findings, it is important to highlight the limitations of the present study and explore avenues for future research. Our study was based on the fashion industry of Pakistan but consumer behavior in social media marketing setting might be different for other industries like tourism and electronics etc. Therefore, future studies can be carried out in different industries. We did not check the moderating role of demographic variables like age, income, and occupation etc. so this limitation can also be addressed by researchers in the near future. The present study was carried out in Pakistan which is an emerging Asian economy and where consumer behavior might be different from other countries. Therefore, we suggest that our model can be tested in different cultural settings in order to draw useful insights. The current study is limited to only socialization motivation. Future researchers can extend the list of motives and establish linkages among motives, attitudes, trust and behavioral intentions in the context of social media marketing environment. We did not check the mediating role of trust on social media retailers which can be addressed in future. Besides these limitations, the study was cross-sectional in nature whereas for capturing changes in intentions and behavior, longitudinal studies are required which might be carried out in future.

\section{REFERENCES}

Ahmad, S., Mustafa, M., \& AhsanUllah. (2016). Association of demographics, motives and intensity of using social networking sites with the formation of bonding and bridging social capital in Pakistan. Computers in Human Behavior, 57, 107-114. https://doi.org/10.1016/j.chb.2015.12.027

Akar, E., \& Topcu, B. (2011). An examination of the factors influencing consumers' attitudes toward social media marketing. Journal of Internet Commerce, 10(1), 3567. https://doi.org/10.1080/15332861.2011.558456 
Aladwani, A. M. (2018). A quality-facilitated socialization model of social commerce decisions. International Journal of Information Management, 40(October 2017), 1-7. https://doi.org/10.1016/j.ijinfomgt.2018.01.006

Alalwan, A. A. (2018). Investigating the impact of social media advertising features on customer purchase intention. International Journal of Information Management, 42(April), 65-77. https://doi.org/10.1016/j.ijinfomgt.2018.06.001

Alalwan, A. A., Rana, N. P., Dwivedi, Y. K., \& Algharabat, R. (2017). Social media in marketing: A review and analysis of the existing literature. Telematics and Informatics, 34(7), 1177-1190. https://doi.org/10.1016/j.tele.2017.05.008

Al-Debei, M. M., Akroush, M. N., \& Ashouri, M. I. (2015). Consumer attitudes towards online shopping: The effects of trust, perceived benefits, and perceived web quality. Internet Research, 25(5), 707-733. https://doi.org/10.1108/IntR-05-2014-0146

Anderson, J. C., \& Gerbing, D. W. (1988). Structural equation modeling in practice: A review and recommended two-step approach. Psychological Bulletin, 103(3), 411-423. https://doi.org/10.1037/0033-2909.103.3.411

Anderson, J. C., \& Gerbing, D. W. (1988). Structural Equation Modeling in Practice: A Review and Recommended Two-Step Approach. Psychological Bulletin, 103(3), 411423. https://doi.org/10.1037/0033-2909.103.3.411

Anderson, K. C., Knight, D. K., Pookulangara, S., \& Josiam, B. (2014). Influence of hedonic and utilitarian motivations on retailer loyalty and purchase intention: A facebook perspective. Journal of Retailing and Consumer Services, 21, 773-779. https://doi.org/10.1016/j.jretconser.2014.05.007

Ashnai, B., Henneberg, S. C., Naudé, P., \& Francescucci, A. (2016). Inter-personal and inter-organizational trust in business relationships: An attitude-behavior-outcome model. Industrial Marketing Management, 52, 128-139. https://doi.org/10.1016/j.indmarman.2015.05.020

Ashraf, A. R., Thongpapanl, N. (Tek), \& Auh, S. (2014). The application of the technology acceptance model under different cultural contexts: The case of online shopping adoption. Journal of International Marketing, 22(3), 68-93. https://doi.org/10.1509/jim.14.0065

Aziz, S., Md Husin, M., Hussin, N., \& Afaq, Z. (2019). Factors that influence individuals' intentions to purchase family takaful mediating role of perceived trust. Asia Pacific Journal of Marketing and Logistics, 31(1), 81-104. https://doi.org/10.1108/APJML12-2017-0311

Ball, J. G., Manika, D., \& Stout, P. (2016). Causes and consequences of trust in direct-toconsumer prescription drug advertising. International Journal of Advertising, 35(2), 216-247. https://doi.org/10.1080/02650487.2015.1009346

Chi, H. (2011). Interactive digital advertising vs. virtual brand community: Exploratory study of user motivation and social media marketing responses in taiwan. Journal of Interactive Advertising, 12(1), 44-61. https://doi.org/10.1046/j.1365-2958.2003.03368. $\mathrm{x}$

Chiang, H.-S., \& Hsiao, K.-L. (2015). YouTube stickiness: The needs, personal, and environmental perspective. Internet Research, 25(1), 85-106. https://doi.org/10.1108/IntR-11-2013-0236

Corkindale, D., Ram, J., \& Chen, H. (2018). The adoption of firm-hosted online communities: an empirical investigation into the role of service quality and social interactions. Enterprise Information Systems, 12(2), 173-195. https://doi.org/10.1080/17517575.2017.1287431 
Online Journal of Communication and Media Technologies, 2019

Dao, W. V. T., Le, A. N. H., Cheng, J. M. S., \& Chen, D. C. (2014). Social media advertising value: The case of transitional economies in Southeast Asia. International Journal of Advertising, 33(2), 37-41. https://doi.org/10.2501/IJA-33-2-271-294

Dijkmans, C., Kerkhof, P., \& Beukeboom, C. J. (2015). A stage to engage: Social media use and corporate reputation. Tourism Management, 47, 58-67. https://doi.org/10.1016/j.tourman.2014.09.005

Dittmar, H., Long, K., \& Meek, R. (2004). Buying on the internet: Gender dfferences in on-line and conventional buying motivations. Sex Roles, 50(5/6), 423-444. https://doi.org/10.1023/b:sers.0000018896.35251.c7

Dolan, R., Conduit, J., Fahy, J., \& Goodman, S. (2016). Social media engagement behaviour: A uses and gratifications perspective. Journal of Strategic Marketing, 24(3), 261-277. https://doi.org/10.1080/0965254X.2015.1095222

eMarketer. (2016). Marketing in Asia-Pacific: Millennials in Vietnam are social, skeptical and seeking role models. Retrieved from https://www.emarketer.com/Article/ Marketing-Asia-Pacific-Millennials-Vietnam-Social-Skeptical-Seeking-Role-Models/ 1014010

Erkan, I., \& Evans, C. (2018). Social media or shopping websites? The influence of eWOM on consumers' online purchase intentions. Journal of Marketing Communications, 24(6), 617-632. https://doi.org/10.1080/13527266.2016.1184706

Fornell, C., \& Larcker, D. F. (1981). Evaluating structural equation models with unobservable variables and measurements error. Journal of Marketing Research, 18, $39-50$.

Gentina, E., Shrum, L. J., Lowrey, T. M., Vitell, S. J., \& Rose, G. M. (2018). An integrative model of the influence of parental and peer support on consumer ethical beliefs: The mediating role of self-esteem, power, and materialism. Journal of Business Ethics, 150(4), 1173-1186. https://doi.org/10.1007/s10551-016-3137-3

Godey, B., Manthiou, A., Pederzoli, D., Rokka, J., Aiello, G., Donvito, R., \& Singh, R. (2016). Social media marketing efforts of luxury brands: Influence on brand equity and consumer behavior. Journal of Business Research, 69(12), 5833-5841. https://doi.org/10.1016/j.jbusres.2016.04.181

GWI. (2019a). Social commerce in 2019. Retrieved from https://www.globalwebindex.com/hubfs/Downloads/Social-commerce-report.pdf

GWI. (2019b). Social media by generation.

Hair, J. F., Black, W. C., Babin, B. J., \& Anderson, R. E. (2010). Multivariate data analysis (7th ed.). New Jersey: Pearson Prentice Hall.

Hawk, S. T., van den Eijnden, R. J. J. M., van Lissa, C. J., \& ter Bogt, T. F. M. (2019). Narcissistic adolescents' attention-seeking following social rejection: Links with social media disclosure, problematic social media use, and smartphone stress. Computers in Human Behavior, 92, 65-75. https://doi.org/10.1016/j.chb.2018.10.032

Hilverda, F., Kuttschreuter, M., \& Giebels, E. (2017). Social media mediated interaction with peers, experts and anonymous authors: Conversation partner and message framing effects on risk perception and sense-making of organic food. Food Quality and Preference, 56, 107-118. https://doi.org/10.1016/j.foodqual.2016.09.003

Hossain, M. A. (2019). Effects of uses and gratifications on social media use. PSU Research Review, 3(1), 16-28. https://doi.org/10.1108/PRR-07-2018-0023

Irshad, M. (2018). Impact of consumers' motivations and trust on attitudes towards social media marketing and purchase intentions. In 2018 Summer AMA Conference Proceeedings (p. 523). 
Izquierdo-Yusta, A., Olarte-Pascual, C., \& Reinares-Lara, E. (2015). Attitudes toward mobile advertising among users versus non-users of the mobile Internet. Telematics and Informatics, 32(2), 355-366. https://doi.org/10.1016/j.tele.2014.10.001

Jabeur, N., Nait-Sidi-Moh, A., \& Zeadally, S. (2017). Crowd social media computing: Applying crowd computing techniques to social media. Applied Soft Computing Journal, 66, 495-505. https://doi.org/10.1016/j.asoc.2017.09.026

Jung, J., Shim, S. W., \& Jin, H. S. (2015). Factors affecting attitudes and behavioural intention towards social networking advertising : a case of Facebook users in South Korea. International Journal of Advertising, 0487(March), 37-41. https://doi.org/10.1080/02650487.2015.1014777

Kaushik, A. K., Agrawal, A. K., \& Rahman, Z. (2015). Tourist behaviour towards selfservice hotel technology adoption: Trust and subjective norm as key antecedents. Tourism Management Perspectives, $\quad 16, \quad 278-289$. https://doi.org/10.1016/j.tmp.2015.09.002

Kim, H. Y., \& Chung, J.-E. (2011). Consumer purchase intention for organic personal care products. Journal of Consumer Marketing, 28(1), 40-47. https://doi.org/10.1108/07363761111101930

Kline, R. B. (2016). Principles and practice of structural equation modeling (4th ed.). New York: The Guilford Press.

Knoll, J. (2015). Advertising in social media: a review of empirical evidence. International Journal of Advertising, 35(2), 266-300. https://doi.org/10.1080/02650487.2015. 1021898

Kumar, A., \& Kashyap, A. K. (2018). Leveraging utilitarian perspective of online shopping to motivate online shoppers. International Journal of Retail and Distribution Management, 46(3), 247-263. https://doi.org/10.1108/IJRDM-08-2017-0161

Lin, J., Wang, B., Wang, N., \& Lu, Y. (2014). Understanding the evolution of consumer trust in mobile commerce: A longitudinal study. Information Technology and Management, 15(1), 37-49. https://doi.org/10.1007/s10799-013-0172-y

Liu, J., North, M., \& Li, C. (2017). Relationship building through reputation and tribalism on company Facebook pages: A uses and gratifications approach. Internet Research, 27(5), 1149-1169. https://doi.org/10.1108/IntR-03-2016-0078

Luna-Nevarez, C., \& Torres, I. M. (2015). Consumer attitudes toward social network advertising. Journal of Current Issues \& Research in Advertising, 36(1), 1-19. https://doi.org/10.1080/10641734.2014.912595

Melancon, J. P., \& Dalakas, V. (2018). Consumer social voice in the age of social media: Segmentation profiles and relationship marketing strategies. Business Horizons, 61(1), 157-167. https://doi.org/10.1016/j.bushor.2017.09.015

Michopoulou, E., \& Moisa, D. G. (2019). Hotel social media metrics: The ROI dilemma. International Journal of Hospitality Management, 76, 308-315. https://doi.org/10.1016/j.ijhm.2018.05.019

Mishra, A., Maheswarappa, S. S., Maity, M., \& Samu, S. (2018). Adolescent's eWOM intentions: An investigation into the roles of peers, the Internet and gender. Journal of Business Research, 86(October 2016), 394-405. https://doi.org/10.1016/j.jbusres.2017.04.005

Mishra, A. S. (2019). Antecedents of consumers' engagement with brand-related content on social media. Marketing Intelligence and Planning, 37(4), 386-400. https://doi.org/10.1108/MIP-04-2018-0130 
Mosquera, A., Olarte-Pascual, C., Ayensa, E. J., \& Murillo, Y. S. (2018). The role of technology in an omnichannel physical store Assessing the moderating effect of gender. Spanish Journal of Marketing - ESIC, 22(1), 63-82. https://doi.org/10.1108/SJME-03-2018-008

Mowbray, J., Hall, H., Raeside, R., \& Robertson, P. (2017). The role of networking and social media tools during job search: An information behaviour perspective. Information Research, 22(1), 1-18. Retrieved from http://informationr.net/ir/221/colis/colis1615.html

MSI. (2014). Research priorities 2014-2016. Marketing Science Institute.

Muk, A., \& Chung, C. (2015). Applying the technology acceptance model in a two-country study of SMS advertising. Journal of Business Research, 68(1), 1-6. https://doi.org/10.1016/j.jbusres.2014.06.001

Muk, A., Chung, C., \& Kim, J. (2014). Korean consumer perspectives on social media advertising and intention to join brand pages. Journal of Global Scholars of Marketing Science, 24(4), 384-394. https://doi.org/10.1080/21639159.2014.949371

Muralidharan, S., \& Men, L. R. (2015). How peer communication and engagement motivations influence social media shopping behavior: Evidence from China and the United States. Cyberpsychology, Behavior, and Social Networking, 18(10), 595-601. https://doi.org/10.1089/cyber.2015.0190

Nadeem, W., Andreini, D., Salo, J., \& Laukkanen, T. (2015). Engaging consumers online through websites and social media: A gender study of Italian Generation Y clothing consumers. International Journal of Information Management, 35(4), 432-442. https://doi.org/10.1016/j.ijinfomgt.2015.04.008

Niu, H. J. (2013). Cyber peers' influence for adolescent consumer in decision-making styles and online purchasing behavior. Journal of Applied Social Psychology, 43, 1228-1237. https://doi.org/10.1111/jasp.12085

Nwagwu, W. E., \& Famiyesin, B. (2016). Acceptance of mobile advertising by consumers in public service institutions in Lagos, Nigeria. Electronic Library, 34, 265-288. https://doi.org/10.1108/el-09-2014-0169

Odoom, R., Anning-Dorson, T., \& Acheampong, G. (2017). Antecedents of social media usage and performance benefits in small- and medium-sized enterprises (SMEs). Journal of Enterprise Information Management, 30(3), 383-399. https://doi.org/10.1108/JEIM-04-2016-0088

Pantano, E., Priporas, C. V., \& Migliano, G. (2019). Reshaping traditional marketing mix to include social media participation: Evidence from Italian firms. European Business Review. https://doi.org/10.1108/EBR-08-2017-0152

Parsons, A. L., \& Lepkowska-White, E. (2018). Social media marketing management: A conceptual framework. Journal of Internet Commerce, 17(2), 81-95. https://doi.org/10.1080/15332861.2018.1433910

PAS. (2015). Digital, social \& mobile in APAC in 2015. Retrieved from http://www.pas.org.pk/digital-social-mobile-in-apac-in-2015/

Paul, J., Modi, A., \& Patel, J. (2016). Predicting green product consumption using theory of planned behavior and reasoned action. Journal of Retailing and Consumer Services, 29, 123-134. https://doi.org/10.1016/j.jretconser.2015.11.006

PBS. (2013). Pakistan social and living standards measurement. Retrieved from http://www.pbs.gov.pk/content/pakistan-social-and-living-standards-measurementsurvey-pslm-2012-13-provincial-district 
Pirson, M., Martin, K., \& Parmar, B. (2017). Formation of stakeholder trust in business and the role of personal values. Journal of Business Ethics, 145(1), 1-20. https://doi.org/10.1007/s10551-015-2839-2

Pletikosa Cvijikj, I., \& Michahelles, F. (2013). Online engagement factors on Facebook brand pages. Social Network Analysis and Mining, 3(4), 843-861. https://doi.org/10.1007/s13278-013-0098-8

Plume, C. J., \& Slade, E. L. (2018). Sharing of sponsored advertisements on social media : A uses and gratifications perspective. Information Systems Frontiers, 20, 471-483. https://doi.org/10.1007/s10796-017-9821-8

Pöyry, E., Parvinen, P., \& Malmivaara, T. (2013). Can we get from liking to buying? Behavioral differences in hedonic and utilitarian Facebook usage. Electronic Commerce Research and Applications, 12, 224-235. https://doi.org/10.1016/j.elerap.2013.01.003

Rahman, M. A., Islam, M. A., Esha, B. H., Sultana, N., \& Chakravorty, S. (2018). Consumer buying behavior towards online shopping: An empirical study on Dhaka city, Bangladesh. Cogent Business and Management, 5(1), 1-22. https://doi.org/10.1080/23311975.2018.1514940

Shankar, V., \& Batra, R. (2009). The growing influence of online marketing communications. Journal of Interactive Marketing, 23(4), 285-287. https://doi.org/10.1016/j.intmar.2009.07.006

Shao, Z., Zhang, L., Li, X., \& Guo, Y. (2019). Antecedents of trust and continuance intention in mobile payment platforms: The moderating effect of gender. Electronic $\begin{array}{lllll}\text { Commerce Research and } & \text { Applications, } & 33, & \end{array}$ https://doi.org/10.1016/j.elerap.2018.100823

Statista. (2019a). Facebook- Statistics \& Facts. Retrieved from https://www.statista.com/topics/751/facebook/

Statista. (2019b). Number of monthly active Instagram users from January 2013 to June 2018 (in millions). Retrieved from https://www.statista.com/statistics/253577/ number-of-monthly-active-instagram-users/

Statista. (2019c). Number of monthly active Twitter users worldwide from 1st quarter 2010 to 1st quarter 2019 (in millions). Retrieved from https://www.statista.com/statistics/282087/number-of-monthly-active-twitter-users/

Statista. (2019d). Pinterest - Statistics \& Facts. Retrieved from https://www.statista.com/topics/1267/pinterest/

Statista. (2019e). YouTube - Statistics \& Facts. Retrieved from https://www.statista.com/topics/2019/youtube/

Taylor, D. G., Lewin, J. E., \& Strutton, D. (2011). Friends , fans , and followers : Do ads work on social Nnetworks? How gender and age shape receptivity. Journal of Advertising Research, 51(1), 258-276. https://doi.org/10.2501/JAR-51-1-258-275

Thongsri, N., Shen, L., Bao, Y., \& Alharbi, I. M. (2018). Integrating UTAUT and UGT to explain behavioural intention to use M-learning: A developing country's perspective. Journal of Systems and Information Technology, 20(3), 278-297. https://doi.org/10.1108/JSIT-11-2017-0107

Valos, M. J., Habibi, F. H., Casidy, R., Driesener, C. B., \& Maplestone, V. L. (2016). Exploring the integration of social media within integrated marketing communication frameworks Perspectives of services marketers. Marketing Intelligence \& Planning, 34(1), 19-40. https://doi.org/10.1108/MIP-09-2014-0169 
Van Der Heijden, H., Verhagen, T., \& Creemers, M. (2003). Understanding online purchase intentions: contributions from technology and trust perspectives. European Journal of Information Systems, 12(1), 41-48.

Vo, K., Nguyen, T., Pham, D., Nguyen, M., Truong, M., Nguyen, D., \& Quan, T. (2019). Handling negative mentions on social media channels using deep learning. Journal of Information and Telecommunication, $0(0)$, 1-23. https://doi.org/10.1080/24751839.2019.1565652

Wang, X., Yu, C., \& Wei, Y. (2012). Social media peer communication and impacts on purchase intentions: A consumer socialization framework. Journal of Interactive Marketing, 26(4), 198-208. https://doi.org/10.1016/j.intmar.2011.11.004

Wang, Y., Min, Q., \& Han, S. (2016). Understanding the effects of trust and risk on individual behavior toward social media platforms: A meta-analysis of the empirical evidence. Computers in Human Behavior, 56, 34-44. https://doi.org/10.1016/j.chb.2015.11.011

Xie, L., \& Ritchie, B. W. (2019). The motivation, constraint, behavior relationship: A holistic approach for understanding international student leisure travelers. Journal of Vacation Marketing, 25(1), 111-129. https://doi.org/10.1177/1356766717750421

Xu-Priour, D. L., Truong, Y., \& Klink, R. R. (2014). The effects of collectivism and polychronic time orientation on online social interaction and shopping behavior: A comparative study between China and France. Technological Forecasting and Social Change, 88, 265-275. https://doi.org/10.1016/j.techfore.2014.07.010

Zarouali, B., Poels, K., Walrave, M., \& Ponnet, K. (2018). "You talking to me?" The influence of peer communication on adolescents' persuasion knowledge and attitude towards social advertisements. Behaviour and Information Technology, 37(5), 502516. https://doi.org/10.1080/0144929X.2018.1458903

Zhang, J., \& Mao, E. (2016). From online motivations to ad clicks and to behavioral intentions: An empirical study of consumer response to social media advertising. Psychology \& Marketing, 33(3), 155-164. https://doi.org/10.1002/mar

Zhang, M., Guob, L., Huc, M., \& Liu, W. (2016). Influence of customer engagement with company social networks on stickiness: Mediating effect of customer value creation. International Journal of Information Management, 37(3), 229-240. https://doi.org/10.1016/j.ijinfomgt.2016.04.010

Zhu, Y., \& Chen, H. (2015). Social media and human need satisfaction: Implications for social media marketing. Business Horizons, 58, 335-345. https://doi.org/10.1016/j.bushor.2015.01.006

Zong, W., Yang, J., \& Bao, Z. (2019). Social network fatigue affecting continuance intention of social networking services: The case of WeChat users in China's universities. Data Technologies and Applications, 53(1), 123-139. https://doi.org/10.1108/DTA-06-2018-0054

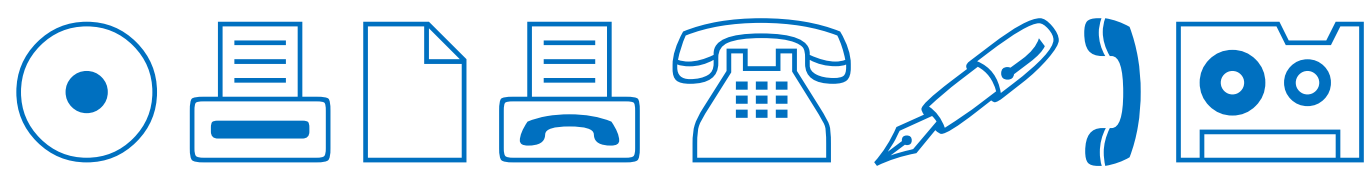

